ROCZNIKI NAUK PRAWNYCH

Tom XXXI, numer $1-2021$

DOI: https://doi.org/10.18290/rnp21311-3

ZUZANNA GĄDZIK

\title{
PRAWNOKARNA OCENA TESTOWANIA PRODUKTÓW KOSMETYCZNYCH NA ZWIERZĘTACH
}

\section{UWAGI WPROWADZAJĄCE}

Pomimo tendencji do dereifikacji zwierząt i związanym z nią ograniczeniem wykorzystywania ich w ramach różnego rodzaju doświadczeń naukowych, nie jest obecnie możliwe całkowite wyeliminowanie tego rodzaju metod badawczych. Ich przeprowadzanie daje bowiem m.in. możliwość pełniejszego poznania działania określonych mechanizmów i weryfikacji wpływu pewnych substancji na funkcjonowanie żywego organizmu. Jednocześnie zauważalne jest zwiększanie znaczenia metod alternatywnych, które pozwalają na uzyskanie równie wiarygodnego wyniku, jak w przypadku testów na żywym organizmie.

Jednym z obszarów badawczych, w ramach którego wykorzystuje się zwierzęta, jest badanie bezpieczeństwa i jakości produktów kosmetycznych. Obszar ten budzi od pewnego czasu spore kontrowersje i poddawany jest krytyce ze strony obrońców praw zwierząt ${ }^{1}$. $Z$ tego też względu sukcesywnie wprowadzane są przepisy dokonujące ograniczenia nie tylko w zakresie przeprowadzania powyższych testów, ale również wdrażania do obrotu produktów kosmetycznych, które były uprzednio testowane na zwierzętach. Ich naruszenie może się wiązać zarówno z odpowiedzialnością administracyjną, jak i karną.

Dr ZuZAnNa GĄDZIK - adiunkt, Katedra Prawa Karnego, Instytut Nauk Prawnych, Wydział Prawa, Prawa Kanonicznego i Administracji Katolickiego Uniwersytetu Lubelskiego Jana Pawła II, Al. Racławickie 14, 20-950 Lublin; e-mail: zuzanna.gadzik@kul.pl; ORCID: https:/orcid.org/ 0000-0002-9121-4658.

${ }^{1}$ Por. np. J. BiaŁocerkiewicz, Status prawny zwierzat. Prawa zwierzą czy prawna ochrona zwierząt, Toruń: Dom Organizatora 2005, s. $281 \mathrm{n}$. 


\section{HUMANITARNA OCHRONA ZWIERZĄT}

Prawna ochrona zwierząt ma charakter wieloaspektowy. $Z$ uwagi na różnorodność obszarów, w których wykorzystywane są zwierzęta, ustawodawca wprowadził przepisy regulujące ich ochronę w sposób kompleksowy. Jednym z podstawowych rodzajów ochrony zwierząt jest ich ochrona humanitarna ${ }^{2}$. Jej zasadniczym celem jest ochrona zwierząt przed zadawaniem im zbędnego bólu lub cierpienia. Bazuje ona na normach zawartych w przepisach ustawy z dnia 21 sierpnia 1997 r. o ochronie zwierząt ${ }^{3}$ - zwłaszcza art. 1 ust. 1 u.o.z. (,Zwierzę, jako istota żyjąca, zdolna do odczuwania cierpienia, nie jest rzeczą. Człowiek jest mu winien poszanowanie, ochronę i opiekę") oraz art. 5 u.o.z. („Każde zwierzę wymaga humanitarnego traktowania”). Jednocześnie należy zaznaczyć, iż zgodnie z przepisem art. 2 u.o.z. ochrona ta odnosi się wyłącznie do zwierząt kręgowych ${ }^{4}$. W ustawie z 21 sierpnia 1997 r. o ochronie zwierząt przewidziano odpowiedzialność karną za nieuzasadnione lub niehumanitarne pozbawienie zwierzęcia życia oraz za znęcanie się nad zwierzętami ${ }^{5}$.

Przyjmuje się, że ochrona humanitarna zwierząt ma charakter dwutorowy. Niektóre z gatunków zwierząt, z uwagi na przyjmowany sposób wykorzystania ich przez człowieka, wymagają bowiem szczególnych warunków traktowania. Konieczne stało się zatem wprowadzenie przepisów, które z jednej strony zapewniałyby tym zwierzętom ochronę przed zadawaniem im zbędnego bólu lub cierpienia, przy jednoczesnym zagwarantowaniu realizacji celów, dla których są one wykorzystywane. Przepisy te zaliczyć należy do tzw. szczególnej ochrony humanitarnej zwierząt. Zalicza się do nich m.in. ustawę z dnia 13 października 1995 r. - Prawo łowieckie ${ }^{6}$ lub ustawę z dnia 15 stycznia 2015 r. o ochronie zwierząt wykorzystywanych do celów naukowych lub edukacyjnych ${ }^{7}$. Powyższe przepisy stanowią lex specialis $\mathrm{w}$ stosunku do generalnej (ogólnej) ochrony humanitarnej zwierząt, dotyczącej wszystkich gatunków

\footnotetext{
${ }^{2}$ Do pozostałych rodzajów ochrony zwierząt zalicza się ochronę gatunkową, użytkową i weterynaryjną. Por. Ł. SMAGA, Ochrona humanitarna zwierzat, Białystok: Agencja Wydawniczo-Edytorska EkoPress 2010, s. 97n.

${ }^{3}$ Ustawa z 21 sierpnia 1997 r. o ochronie zwierząt, t.j. Dz.U. z 2020 r., poz. 638 [dalej: u.o.z.].

${ }^{4}$ Przyjąć należy, biorąc pod uwagę szczególną budowę układu nerwowego kręgowców, że to właśnie dzięki niemu są one zdolne do odczuwania bólu lub cierpienia.

${ }^{5}$ Szerzej na temat genezy regulacji prawnych z zakresu humanitarnej ochrony zwierząt zob. np. M. RuDY, Traktat o uśmiercaniu zwierząt, Warszawa: Wydawnictwo Uniwersytetu SWPS 2019, s. 74n.

${ }^{6}$ Ustawa z 13 października 1995 r. - Prawo łowieckie, t.j. Dz.U. z 2020 r., poz. 1638.

${ }^{7}$ Ustawa z 15 stycznia 2015 r. o ochronie zwierząt wykorzystywanych do celów naukowych lub edukacyjnych, t.j. Dz.U. z 2019 r., poz. 1392 [dalej: u.z.n.e.].
} 
zwierząt kręgowych, niezależnie od sposobu ich wykorzystania przez człowieka. Znajdują one zastosowanie w przypadku, gdy określone kwestie nie zostały uregulowane $\mathrm{w}$ ramach ustaw szczegółowych lub gdy z pewnych względów przepisy te nie znajdują zastosowania ${ }^{8}$.

\section{PRODUKT KOSMETYCZNY I DOPUSZCZALNOŚĆ TESTOWANIA PRODUKTÓW KOSMETYCZNYCH NA ZWIERZĘTACH}

Definicja produktu kosmetycznego zawarta została w przepisie art. 2 ust. 1 lit. a rozporządzenia Parlamentu Europejskiego i Rady (WE) nr 1223/2009 z dnia 30 listopada 2009 r. dotyczącego produktów kosmetycznych ${ }^{9}$, do którego odsyła przepis art. 2 pkt 9 ustawy z dnia 4 października 2018 r. o produktach kosmetycznych ${ }^{10}$. Zgodnie $\mathrm{z}$ nim produktem kosmetycznym jest każda substancja lub mieszanina przeznaczona do kontaktu z zewnętrznymi częściami ciała ludzkiego (naskórkiem, owłosieniem, paznokciami, wargami oraz zewnętrznymi narządami płciowymi) lub z zębami oraz błonami śluzowymi jamy ustnej, którego wyłącznym lub głównym celem jest utrzymywanie ich w czystości, perfumowanie, zmiana ich wyglądu, ochrona, utrzymywanie w dobrej kondycji lub korygowanie zapachu ciała. Zgodnie z motywem 7 rozporządzenia nr 1223/2009 ustalenie, czy dany produkt należy uznać za produkt kosmetyczny, musi być dokonywane na podstawie indywidualnej oceny produktu, uwzględniającej wszystkie jego cechy. Produkty kosmetyczne mogą obejmować zatem kremy, emulsje, płyny, żele i oliwki do skóry, maseczki do twarzy, podkłady barwiące (płyny, pasty, pudry), pudry do makijażu, pudry po kąpieli, pudry higieniczne, mydła toaletowe, mydła dezodoryzujące, perfumy, wody toaletowe i kolońskie, środki do kąpieli i pod prysznic (sole, pianki, oliwki, żele), depilatory, dezodoranty i środki przeciw poceniu, barwniki do włosów, produkty do trwałej ondulacji, do prostowania i utrwalania włosów, produkty do układania włosów, produkty do mycia włosów (płyny, proszki, szampony), odżywki do włosów (płyny, kremy, oliwki), produkty do

\footnotetext{
${ }^{8}$ Zob. Z. GĄDZIK, Środki karne, przepadek zwierzęcia i nawiązka w ustawie z dnia 21 sierpnia 1997 r. o ochronie zwierzat, „, Prokuratura i Prawo” 2019, nr 3, s. 77.

${ }^{9}$ Rozporządzenie Parlamentu Europejskiego i Rady (WE) nr 1223/2009 z 30 listopada 2009 r. dotyczące produktów kosmetycznych, Dz.U. UE.L Nr 342, poz. 59 [dalej: rozporządzenie $\mathrm{nr}$ 1223/2009].

${ }^{10}$ Ustawa z 4 października 2018 r. o produktach kosmetycznych, Dz.U. poz. 2227 [dalej: u.o.p.k.].
} 
układania fryzury (płyny, lakiery, brylantyna), produkty do golenia (kremy, pianki, płyny), produkty do makijażu i de-makijażu, produkty przeznaczone do warg, produkty do pielęgnacji zębów i jamy ustnej, produkty do pielęgnacji i malowania paznokci, produkty do higieny intymnej, produkty do opalania, produkty do samoopalania, produkty do rozjaśniania skóry i środki przeciw zmarszczkom ${ }^{11}$.

W odróżnieniu od obowiązującej poprzednio ustawy z dnia 30 marca $2001 \mathrm{r}$. o kosmetykach ${ }^{12}$, ustawa z dnia 4 października 2018 r. o produktach kosmetycznych nie zawiera przepisów wprost wyrażających zakaz przeprowadzania testów produktów kosmetycznych na zwierzętach, wprowadzania do obrotu produktów, które były testowane na zwierzętach lub zawierają składniki, lub ich kombinacje testowane na zwierzętach, jak również przeprowadzania na zwierzętach testów składników produktów kosmetycznych lub kombinacji tych składników ${ }^{13}$. Odpowiednie obowiązujące zakazy wyprowadzić należy jednak z interpretacji przepisów art. 34 i 35 u.o.p.k., przewidujących odpowiedzialność w postaci kar pieniężnych za naruszenie zakazów w zakresie testów na zwierzętach, o których mowa w art. 18 ust. 1 rozporządzenia nr 1223/2009. Biorąc powyższe pod uwagę, niedozwolone jest: a) wprowadzanie do obrotu produktów kosmetycznych, których receptura końcowa podlegała testom na zwierzętach przy użyciu metod innych niż metody alternatywne, po tym jak takie metody alternatywne zostały uznane i przyjęte na poziomie wspólnotowym z uwzględnieniem postępu walidacji w ramach Organizacji Współpracy Gospodarczej i Rozwoju (dalej: OECD); b) wprowadzanie do obrotu produktów kosmetycznych zawierających składniki lub ich kombinacje, które były testowane na zwierzętach przy zastosowaniu metod innych niż metody alternatywne, mimo że takie metody alternatywne zostały uznane i przyjęte na poziomie wspólnotowym z uwzględnieniem postępu walidacji w ramach OECD; c) prowadzenie we Wspólnocie testów gotowych produktów kosmetycznych na zwierzętach; d) prowadzenie we Wspólnocie testów na zwierzętach dotyczących składników lub kombinacji składników po dniu, w którym wymagane jest zastąpienie takich testów przez jedną lub więcej zatwierdzonych metod alternatywnych, wymienionych w rozporządzeniu Komisji (WE) $\mathrm{nr}$ 440/2008 z dnia 30 maja 2008 r. ustalającym metody badań zgodnie

\footnotetext{
${ }^{11}$ Zob. szerzej: M. BorKowski, Prawo kosmetyczne. Zarys prawa polskiego i europejskiego, Gdańsk: Wydawnictwo Gdańskiej Szkoły Wyższej 2015, s. 46n.

${ }^{12}$ Ustawa z 30 marca 2001 r. o kosmetykach, tekst jedn.: Dz.U. z 2013 r., poz. 475.

${ }^{13}$ Por. D. WĄSIK, Ustawa o kosmetykach. Komentarz, Warszawa: Wolters Kluwer 2016, s. 39n.; B. KURZĘPA, Ustawa o kosmetykach z komentarzem, Toruń: Dom Organizatora 2009, s. 53n.
} 
z rozporządzeniem (WE) nr 1907/2006 Parlamentu Europejskiego i Rady w sprawie rejestracji, oceny, udzielania zezwoleń i stosowanych ograniczeń w zakresie chemikaliów (RE-ACH) ${ }^{14}$ lub w załączniku VIII do rozporządzenia nr 1223/2009.

Biorąc pod uwagę zakres powyższych zakazów, należy uznać, że testowanie produktów kosmetycznych na zwierzętach nie zawsze będzie zachowaniem bezprawnym. Bezwzględny zakaz dotyczy gotowych produktów kosmetycznych, a więc takich, które są zgodne ze swoją recepturą końcową w postaci, w jakiej są wprowadzane do obrotu i udostępniane użytkownikowi końcowemu, lub prototypy takich produktów (art. 18 ust. 3 lit. a rozporządzenia nr 1223/ 2009). Pewne ograniczenia w zakazie przeprowadzenia testów na zwierzętach odnosić się będą natomiast do poszczególnych składników produktów kosmetycznych, czyli wchodzących $w$ skład ich receptury substancji ${ }^{15}$ bądź ich $\operatorname{mieszanin}^{16}$.

Dopuszczalność testowania na zwierzętach poszczególnych składników produktów kosmetycznych oprzeć należy na uregulowaniach prawnych zawartych w przepisach ustawy z dnia 15 stycznia 2015 r. o ochronie zwierząt wykorzystywanych do celów naukowych lub edukacyjnych. W określonych przypadkach dopuszczalne będzie bowiem przeprowadzanie procedur doświadczalnych ${ }^{17}$ odnoszących się do tego rodzaju substancji lub ich mieszanin. Przepis art. 3 u.z.n.e. zawiera katalog zamknięty celów, dla których dopuszczalne jest przeprowadzenie procedury doświadczalnej na zwierzętach.

\footnotetext{
${ }^{14}$ Rozporządzenie Komisji (WE) nr 440/2008 z dnia 30 maja 2008 r. ustalające metody badań zgodnie z rozporządzeniem (WE) nr 1907/2006 Parlamentu Europejskiego i Rady w sprawie rejestracji, oceny, udzielania zezwoleń i stosowanych ograniczeń w zakresie chemikaliów (REACH), Dz.U. UE.L. Nr 142, poz. 1.

${ }^{15}$ Zgodnie z przepisem art. 1 ust. 1 lit. b rozporządzenia nr 1223/2009 substancją jest pierwiastek chemiczny i jego związki w stanie, w jakim występują w przyrodzie lub zostają uzyskane za pomocą procesu produkcyjnego, z wszelkimi dodatkami wymaganymi do zachowania ich trwałości oraz wszelkimi zanieczyszczeniami powstałymi w wyniku zastosowanego procesu, wyłączając rozpuszczalniki, które można oddzielić bez wpływu na stabilność lub zmiany jej składu.

${ }^{16}$ Zgodnie z przepisem art. 1 ust. 1 lit. c rozporządzenia nr 1223/2009 przez mieszaninę należy rozumieć mieszaninę lub roztwór składający się z dwóch lub więcej substancji.

${ }^{17}$ Procedurą doświadczalną jest każda forma wykorzystania zwierząt do celów określonych w art. 3 u.z.n.e., która może spowodować u zwierzęcia ból, cierpienie, dystres lub trwałe uszkodzenie organizmu, w stopniu równym ukłuciu igłą lub intensywniejszym, a także czynności mające na celu lub mogące spowodować urodzenie się lub wylęg zwierzęcia albo powstanie i utrzymanie genetycznie zmodyfikowanej linii zwierząt w warunkach bólu, cierpienia, dystresu lub trwałego uszkodzenia organizmu, w stopniu równym ukłuciu igłą lub intensywniejszym; nie jest procedurą uśmiercenie zwierzęcia wyłącznie po to, aby wykorzystać jego narządy lub tkanki do celów określonych w art. 3 u.z.n.e. (art. 2 ust. 1 pkt 6 u.z.n.e.).
} 
W kontekście testowania składników produktów kosmetycznych wskazać należy cel dotyczący opracowania i produkcji innych niż produkty lecznicze, środki spożywcze bądź pasze substancji lub produktów, a także badania ich jakości, skuteczności lub bezpieczeństwa stosowania, przeprowadzanych w celach: zapobiegania chorobom, diagnozowania lub leczenia chorób bądź dysfunkcji u ludzi, zwierząt lub roślin; oceny, wykrywania, regulacji lub zmiany stanów fizjologicznych ludzi, zwierząt lub roślin; zapewnienia dobrostanu zwierząt lub poprawy warunków chowu, lub hodowli zwierząt gospodarskich. W ramach tej kategorii mieścić się bowiem będą m.in. badania toksyczności oraz inne badania bezpieczeństwa poszczególnych substancji lub ich mieszanin, mających znaczenie m.in. w kontekście wpływania na stany fizjologiczne ludzi bądź zwierząt (np. ich skóry lub włosów).

Przez toksykologię rozumie się dyscyplinę naukową, której przedmiotem jest badanie aktualnych lub potencjalnych niebezpieczeństw związanych z działaniem określonych substancji chemicznych. Dotyczy ona ich wpływu na żywe organizmy, jak również na całe ekosystemy. Przypisywanym jej celem jest m.in. przeprowadzanie badań, które pozwalają na ustalenie szkodliwego działania określonych związków chemicznych, ocenę ryzyka dla organizmów żywych, zalecanych środków kontroli, zapobiegania szkodliwym skutkom ich działania, a także rozpoznawanie i leczenie zatrućc ${ }^{18}$.

Testowanie na zwierzętach toksyczności substancji wchodzących w skład produktów kosmetycznych może przybrać różnorodną formę - przykładowo: w jego ramach mieszczą się badania, które mają na celu stwierdzenie działania drażniącego bądź uczulającego skórę lub drażniącego na oczy. Do jednych z najbardziej popularnych badań tego rodzaju zalicza się test Draize’a. Celem jego przeprowadzenia jest zweryfikowanie, jaka ilość danej substancji będzie wystarczająca dla wywołania określonych niepożądanych efektów u zwierzęcia (np. swędzenia, obrzęku, krwawienia, utraty widzenia). Przeprowadzający tego typu doświadczenie badają rodzaj zmian chorobowych powstających pod wpływem zastosowania testowanego środka. Test ten wywołuje spore kontrowersje. Sposób, w jaki podawana jest dana substancji, uniemożliwia bowiem pozbycie się jej przez zwierzę z zaaplikowanego miejsca - zwierzęta są zwykle

${ }^{18}$ Zob. J. KrechniaK, Toksykologia - zakres działania i kierunki rozwoju, [w:] Toksykologia wspótczesna, red. W. Seńczuk, Warszawa: Wydawnictwo Lekarskie PZWL 2006, s. 24; por. E. GoMÓŁKA, B. GRosZeK, Rola i znaczenie badań toksykologicznych, [w:] Zarys toksykologii klinicznej, red. J. Pach, Kraków: Wydawnictwo Uniwersytetu Jagiellońskiego 2009, s. 71n.; W. BuCZKO, Toksykologia ogólna, [w:] Farmakodynamika. Podręcznik dla studentów farmacji, red. W. Janiec, J. Krupińska, Warszawa: Wydawnictwo Lekarskie PZWL 1999, s. 68n. 
odpowiednio unieruchamiane, aby uniemożliwić im podrapanie się, wylizanie bądź potarcie podrażnionego miejsca. W rezultacie podana substancja nie może być w żaden sposób wypłukiwana lub usuwana. Zwiększa to tym samym prawdopodobieństwo wystąpienia stanów zapalnych i innych podrażnieńn ${ }^{19}$. Wśród innych rodzajów testów toksyczności, wykorzystywanych w ramach badania składników produktów kosmetycznych, wymienić można ponadto: badania toksyczności ostrej $\left(\mathrm{LD}_{50}\right)$, toksyczności podostrej, toksyczności podprzewlekłej, toksyczności przewlekłej, działania teratogennego lub działania rakotwórczego etc. ${ }^{20}$

W kontekście legalności testowania składników produktów kosmetycznych na zwierzętach podkreślić należy, że dla uznania określonego przedsięwzięcia jako procedury doświadczalnej, konieczne jest spełnienie szeregu warunków formalnych (dotyczących m.in. przeprowadzenia procedury przez uprawniony do tego podmiot, uzyskania zgody ze strony lokalnej komisji etycznej, posiadający odpowiednie warunki do podjęcia tego typu działalności ${ }^{21}$. W przeciwnym razie podjęte zachowania nie będą stanowiły procedury doświadczalnej, a tym samym niedopuszczalne będzie stosowanie wobec nich przepisów ustawy z dnia 15 stycznia 2015 r. o ochronie zwierząt wykorzystywanych do celów naukowych lub edukacyjnych - zwłaszcza w zakresie dopuszczalności zadawania zwierzętom bólu lub cierpienia. Dodatkowe obostrzenia wprowadzają ponadto przepisy rozporządzenia $\mathrm{nr} 1223 / 2009$. Co do zasady niedopuszczalne będzie przeprowadzenie takiej procedury, jeżeli dopuszczalne będzie zastąpienie testów na zwierzętach zaakceptowaną metodą alternatywną. Zgodnie $\mathrm{z}$ motywem $\mathrm{nr} 42$ powyższego rozporządzenia stopniowo

${ }^{19}$ Zob. T. PIETRZYKOWSKI, Spór o prawa zwierząt, Katowice: Sonia Draga 2007, s. 38; por. także: W. PAton, Człowiek i mysz: badania medyczne na zwierzętach, Warszawa: Wydawnictwo Naukowe PWN 1997, s. 185n.; S. Moskalewski, E.T. MystKowsKA, E. KISS, Test Draize'a i alternatywne metody oceny działania drażniacego substancji chemicznych, „Roczniki Państwowego Zakładu Higieny" 1995, nr 2; L. CARBone, What Animals Want: Expertise and Advocacy in Laboratory Animal Welfare Policy, Oxford: Oxford Scholarship Online 2004, s. 23n.; D.J. ECOBICHON, The Basis of Toxicity Testing, New York: RC Press LLC 1997, s. 62n.; A.N. RowAN, Of Mice, Models, and Men: A Critical Evaluation of Animal Research, New York: SUNY Press 1984, s. 217n.

${ }^{20}$ Zob. D. BARSKI, Wybrane testy toksykologiczne z użyciem zwierzat laboratoryjnych, [w:] Zwierzęta laboratoryjne. Patologia i użytkowanie, red. J. Szarek, M. Szweda, E. Strzyżewska, Olsztyn: Wydawnictwo Uniwersytetu Warmińsko-Mazurskiego 2013, s. 136; por. A. BANASZKIEWICZ, Zarys problematyki przeprowadzania doświadczeń na zwierzętach w przemyśle kosmetycznym, [w:] Kryminologia wobec wspótczesnych zagrożen ekologicznych, red. M. Kotowska, W. Pływaczewski, Olsztyn: Wydawnictwo Uniwersytetu Warmińsko-Mazurskiego 2011, s. 154n.

${ }^{21}$ Zasady przeprowadzania procedur doświadczalnych zawarte zostały w rozdziale 2 ustawy z dnia 15 stycznia 2015 r. o ochronie zwierząt wykorzystywanych do celów naukowych lub edukacyjnych. 
stanie się możliwe zapewnienie bezpieczeństwa składników stosowanych w produktach kosmetycznych przy użyciu metod alternatywnych, bez wykorzystania zwierząt, przy czym metody te będą uznane na poziomie wspólnotowym lub zatwierdzone naukowo przez Europejskie Centrum Uznawania Metod Alternatywnych (ECVAM) z należytym uwzględnieniem rozwoju uznawania w ramach Organizacji Współpracy Gospodarczej i Rozwoju (OECD). Po konsultacji z Scientific Committee on Consumer Safety (SCCS) w odniesieniu do stosowania uznanych metod alternatywnych w zakresie produktów kosmetycznych, Komisja powinna niezwłocznie ogłosić wykaz uznanych lub zatwierdzonych metod alternatywnych odnoszących się do takich składników. W celu uzyskania możliwie jak najwyższego stopnia ochrony zwierząt należy ustalić nieprzekraczalny termin wprowadzenia całkowitego zakazu.

Przez metody alternatywne rozumieć należy różnego rodzaju techniki zastępcze, które mogą zredukować liczbę wymaganych do badań zwierząt bądź w znacznym stopniu ograniczyć ból, strach i cierpienie zwierząt poddawanych procedurom doświadczalnym ${ }^{22}$. Przyjmuje się, że pozostają one w ścisłym związku z realizacją tzw. zasad „3R” - replacing (zastępowania), refinning (osłabiania) oraz reducting (zmniejszania, zredukowania). Zgodnie z pierwszą ze wskazanych reguł, zwierzęta doświadczalne będące kręgowcami powinny być zastępowane zwierzętami bezkręgowymi bądź w ogóle wyeliminowane na rzecz stosowania metod alternatywnych - np. hodowli in vitro (w ramach hodowli komórkowych, zrekonstruowanych tkanek lub systemów co-culture), ulepszonych lub zmodyfikowanych metod ex vivo (wyizolowanych tkanek zwierzęcych i ich organów) lub in silico (metody polegającej na przeprowadzeniu odpowiednich symulacji komputerowych) ${ }^{23}$. Kolejna z zasad - reffining, sprowadza się do ograniczania cierpienia zwierząt, które zostają poddane procedurom doświadczalnym. Jej realizacja może polegać na zaplanowaniu doświadczenia w taki sposób, aby ograniczyć do minimum cierpienie zwierzęcia doświadczalnego, bądź całkowicie wyeliminować z jego przebiegu elementy bólu, strachu lub stresu. W praktyce przejawia się to zastosowaniem

${ }^{22}$ Por. C. RADZIKOWSKI, Ocena tzw. metod alternatywnych $w$ badaniach biomedycznych, „Nauka” 1995, nr 1, s. 150; A. CHODOROwSKA, Przeprowadzanie doświadczeń na zwierzętach $w$ świetle przepisów prawa polskiego i międzynarodowego, [w:] Prawnokarne i kryminologiczne aspekty ochrony środowiska, red. W. Pływaczewski, Olsztyn: Wydawnictwo Uniwersytetu Warmińsko-Mazurskiego 2012, s. 223n.

${ }^{23}$ Zob. A. PiastowsKa-Ciesielska, T. OChĘDALSKi, Metodologia badań in vitro, Łódź: Biuro Promocji i Wydawnictw Uniwersytetu Medycznego w Łodzi 2010, s. 48n.; K. JUROWSKI, W. PIEKOSZEWSKI, Toksykologia i ocena bezpieczeństwa kosmetyków, Warszawa: Wydawnictwo Lekarskie PZWL 2019, s. 390n.; Ł. SMAGA, Ochrona humanitarna, s. 191. 
środków łagodzących, trankwilizujących, znieczulających miejscowo bądź całkowicie $^{24}$. Zgodnie $\mathrm{z}$ ostatnią ze wspomnianych zasad - reduction, w przypadku gdy metody alternatywne nie umożliwiają zrezygnowania z konieczności użycia zwierzęcia w eksperymencie, należy zmierzać do zmniejszenia liczby osobników, które biorą udział w procedurze doświadczalnej ${ }^{25}$.

Nie wykluczając priorytetowej roli metod alternatywnych w ramach badań jakości i toksyczności poszczególnych składników produktów kosmetycznych, prawodawca wprowadził jednak wyjątek, w przypadku którego możliwe będzie przeprowadzenie testów na zwierzętach pomimo występowania stosownych metod alternatywnych. Zgodnie z art. 18 ust. 2 rozporządzenia $\mathrm{nr}$ 1223/ 2009 odstępstwo to będzie możliwe w wyjątkowych okolicznościach, w przypadku gdy powstaną poważne obawy dotyczące bezpieczeństwa istniejącego składnika kosmetycznego, a ponadto, gdy składnik ten jest w powszechnym użyciu i nie może być zastąpiony innym składnikiem o podobnym działaniu, jak również udowodniony jest szczególny problem zdrowia ludzi, a potrzeba przeprowadzenia testów na zwierzętach jest uzasadniona oraz potwierdzona przez szczegółowy protokół badań, zgłaszany jako podstawa do wydania oce$n y^{26}$. Zgodę w tym względzie wydaje Komisja Europejska.

W przypadku niespełnienia lub naruszenia wymogów związanych z przeprowadzeniem procedury doświadczalnej lub testów produktów kosmetycznych, sprawca naraża się nie tylko na odpowiedzialność administracyjną (związaną z nałożeniem na niego stosownej kary pieniężnej ${ }^{27}$ ), ale również

${ }^{24}$ A. Piastowska-Ciesielska, T. OchęDAlski, Metodologia, s. 49. Za przykład realizacji tej metody można uznać także tzw. humanitarne zakończenie badań (humane end point) - przerwanie badań z chwilą uzyskania odpowiednich danych, jeżeli doświadczenie wiąże się z zadawaniem zwierzętom cierpienia. Zob. A.M. GoldBerG, T. HARTUnG, Na ratunek królikom doświadczalnym, „Świat Nauki” 2006, nr 3, s. 75.

${ }^{25}$ Zob. Etyczne i prawne uwarunkowania wykorzystywania zwierzat w pracy dydaktycznej $i$ badaniach naukowych, oprac. Z. Giżejewski [i in.], Olsztyn: Wydawnictwo Uniwersytetu WarmińskoMazurskiego 2001, s. 17n.; W.M.S. RuSSELL, R.L. BURCH, The Principles of Humane Experimental Technique (chapter 6 - Reduction), tekst dostępny na stronie: http://altweb.jhsph.edu/pubs/books/ humane_exp/chap6a [dostęp: 21.01.2021]; V. MonAmy, Animal experimentation. A guide to the issues, Cambridge: Cambridge University Press 2000, s. 81n.; por. także: M. Fox, Laboratory animal husbandry. Ethology, Welfare and Experimental Variables, New York: State University of New York Press 1986, s. 125n.; I. NowickA, Wykorzystanie zwierząt do badań nad kosmetykami w polskim systemie prawnym - zarys problemu, [w:] Meandry prawa - teoria i praktyka. Księga jubileuszowa prof. zw. dra hab. Mieczysława Goettela, red. E.W. Pływaczewski, J. Bryk, Szczytno: Wydawnictwo Wyższej Szkoły Policyjnej 2017, s. 374.

${ }^{26}$ Por. M. Borkowski, Prawo, s. 108.

${ }^{27}$ Zgodnie z przepisem art. 34 u.o.p.k., kto wprowadza do obrotu produkt kosmetyczny z naruszeniem zakazów w zakresie testów na zwierzętach, o których mowa w art. 18 ust. 1 rozporządzenia 
karną. Jedną z głównych cech prawa karnego jest bowiem jego subsydiarność. Oznacza to, że znajduje ono zastosowanie w ostateczności, gdy zastosowanie środków prawnych z zakresu innych gałęzi prawa okaże się niewystarczające lub gdy nie istnieje możliwość chronienia dobra prawnego w inny sposób ${ }^{28}$.

\section{ODPOWIEDZIALNOŚĆ KARNA \\ ZA TESTOWANIE PRODUKTÓW KOSMETYCZNYCH NA ZWIERZĘTACH}

Na wstępie należy zaznaczyć, że w obecnym stanie prawnym nie przewidziano wprost odpowiedzialności karnej za testowanie produktów kosmetycznych na zwierzętach. Kryminalizacja takiego zachowania przewidziana była natomiast w przepisie art. 40 ustawy z dnia 21 stycznia 2005 r. o doświadczeniach na zwierzętach ${ }^{29}$, zgodnie z którym odpowiedzialność ponosił sprawca przeprowadzający doświadczenia w celu testowania kosmetyków lub środków higienicznych (ust. 1). Przewidziano wówczas również surowszą karalność w przypadku, gdy zachowanie sprawcy wiązało się ze szczególnym okrucieństwem (ust. 2). Powyższe rozwiązanie spotykało się jednak niejednokrotnie $\mathrm{z}$ krytyką, $\mathrm{z}$ uwagi na to, iż z literalnego brzmienia powyższego przepisu wynikało, że zabronione było wyłącznie testowanie na zwierzętach gotowych kosmetyków. Nie dotyczyło to natomiast ich poszczególnych składników ${ }^{30}$. Ustawa z dnia 21 stycznia 2005 r. o doświadczeniach na zwierzętach została uchylona $z$ dniem 25 maja 2015 r.

W obecnym stanie prawnym, w zależności od tego, czy testowanie składników produktów kosmetycznych ma miejsce w ramach procedury doświadczalnej, czy z pewnych powodów przebiega poza jej ramami (przede wszystkim z powodu niespełnienia wszystkich wymaganych przesłanek), sprawca może ponieść odpowiedzialność karną na gruncie przepisów ustawy z dnia

nr 1223/2009, podlega karze pieniężnej w wysokości do 30000 zł. Natomiast zgodnie z przepisem art. 35 u.o.p.k., kto wbrew zakazom wynikającym z art. 18 ust. 1 rozporządzenia nr 1223/2009 przeprowadza testy na zwierzętach, podlega karze pieniężnej w wysokości do 100000 zł. Niezależnie od powyższych przepisów ustawodawca przewidział także właściwe sankcje pieniężne za przekroczenie wymogów formalnych wymaganych w przypadku przeprowadzania procedur doświadczalnych (art. 69 u.z.n.e.).

${ }^{28}$ Por. np. Prawo karne, red. A. Grześkowiak, K. Wiak, Warszawa: C.H. Beck 2017, s. 8.

${ }^{29}$ Ustawa z 21 stycznia 2005 r. o doświadczeniach na zwierzętach, Dz.U. Nr 33, poz. 289 [dalej: u.o.d.z.].

${ }^{30}$ Zob. Ł. SMAGA, Ochrona humanitarna, s. 186, za: J. BożYK, Koniec testów na zwierzętach?, tekst dostępny na stronie: http://www.sprawynauki.waw.pl/?section=article\&art_id=1449 [dostęp: 21.01.2020]. 
15 stycznia 2015 r. o ochronie zwierząt wykorzystywanych do celów naukowych lub edukacyjnych - za narażenie zwierząt na niepotrzebny ból, cierpienie, dystres lub trwałe uszkodzenie ciała (art. 66 ust. 1 pkt 1 u.z.n.e.), wykorzystanie zwierząt $w$ procedurach objętych doświadczeniem bez uzyskania zgody na ich wykorzystanie (art. 66 ust. 1 pkt 2 u.z.n.e.), spowodowanie w wyniku powyższych zachowań śmierci zwierzęcia (art. 66 ust. 2 u.z.n.e.), bądź przepisów ustawy z dnia 21 sierpnia 1997 r. o ochronie zwierząt - za nieuzasadnione lub niehumanitarne pozbawienie zwierzęcia życia (art. 35 ust. 1 u.o.z.) lub znęcanie się nad zwierzętami (art. 35 ust. 1a u.o.z.) ${ }^{31}$. Zaznaczyć również należy, że z uwagi na bezwzględny zakaz testowania gotowych produktów kosmetycznych na zwierzętach niedopuszczalne będzie wyrażenie zgody na tego typu procedurę doświadczalną przez lokalną komisję etyczną. Podjęcie powyższego działania będzie każdorazowo wiązało się z odpowiedzialnością karną na zasadach ogólnych. Wobec powyższego opisane poniżej czyny dotyczyć będą sytuacji testowania na zwierzętach składników produktów kosmetycznych lub ich mieszanin.

W pierwszym ze wspomnianych przypadków czynność sprawcza ma miejsce w ramach procedury doświadczalnej. Procedura ta $z$ samej swojej definicji wiąże się z zadawaniem zwierzętom bólu lub cierpienia, lecz w omawianym przypadku dochodzi do przekroczenia przyjętych w tym względzie granic. Powyższy czyn stanowi przestępstwo materialne - do jego znamion należy skutek w postaci wystąpienia bólu, cierpienia, dystresu lub trwałego uszkodzenia ciała, jeżeli nie było to konieczne i można było ich uniknąć.

Katalog zachowań, które wypełniać będą powyższe znamiona, jest otwarty ${ }^{32}$. Jednym $\mathrm{z}$ nich będzie powtarzanie procedury, która została już przeprowadzona oraz znane są jej wyniki. Zgodnie z przepisem art. 5 ust. 3 u.z.n.e. niedopuszczalne jest wykonanie procedury w celu utrzymania danych, które zostały uzyskane w innych niż Rzeczypospolita Polska państwach członkowskich Unii Europejskiej w wyniku wykonania procedur uznawanych przez prawodawstwo Unii Europejskiej, w szczególności w zakresie pasz, produktów biobójczych, produktów leczniczych, substancji chemicznych, środków ochrony roślin, wyrobów medycznych lub żywności, chyba że potwierdzenie

\footnotetext{
${ }^{31}$ Ustawodawca przewidział również odpowiedzialność za typ kwalifikowany - związany z popełnieniem powyższych czynów ze szczególnym okrucieństwem (art. 35 ust. 2 u.o.z.).

${ }^{32}$ Por. S. MroczKowsKI, A. FrIESKe, Prawne i etyczne aspekty inżynierii biomedycznej. Eksperymenty na zwierzętach i badania kliniczne wyrobów medycznych, Bydgoszcz: Wydawnictwa Uczelniane Uniwersytetu Technologiczno-Przyrodniczego 2014, s. 23n.; Z. GĄDZIK, Prawnokarna ochrona zwierząt wykorzystywanych $w$ procedurach doświadczalnych, Lublin: Wydawnictwo KUL 2018, s. 164n.; W. RADECKI, Ustawy o ochronie zwierząt. Komentarz, Warszawa: Difin 2015, s. 369n.
} 
tych danych jest niezbędne, aby wykorzystać je do badań mających na celu ochronę zdrowia publicznego, bezpieczeństwa lub środowiska naturalnego. Podmiot, który przeprowadza daną procedurę, jest zobowiązany do zapoznania się ze źródłami dotyczącymi badań z udziałem zwierząt. Ma to wyeliminować powtórzenie doświadczenia, które prowadziłoby do uzyskania tych samych wyników ${ }^{33}$. W kontekście przeprowadzania testów produktów kosmetycznych na zwierzętach obowiązek ten wyprowadzić można również z motywu $\mathrm{nr} 41$ rozporządzenia nr 1223/2009. Zgodnie z nim bezpieczeństwo gotowych produktów kosmetycznych można zapewnić już na podstawie wiedzy o bezpieczeństwie ich składników ${ }^{34}$.

Kolejnym przykładem czynności sprawczej czynu stypizowanego w przepisie art. 66 ust. 1 pkt 1 u.z.n.e. jest przeprowadzanie na zbyt wielu osobnikach doświadczenia, które wywołuje ból, strach, cierpienie bądź trwałe uszkodzenia w organizmie zwierzęcia (art. 5 ust. 1 pkt 2 u.z.n.e.). Przez zmniejszenie liczby zwierząt rozumieć należy np. uzyskanie maksymalnej ilości informacji z każdego wykorzystanego w procedurze zwierzęcia, korzystanie z odpowiedniego gatunku dla zapewnienia właściwych wyników, minimalizowanie wpływu zmiennych wpływających na wynik procedury (np. stres, choroby, dieta etc.) ${ }^{35}$. W powyższym kontekście należy powołać również drugi z czynów stypizowany w przepisie art. 66 ust. 1 z.n.e. Zachowanie sprawcy może polegać bowiem na wykorzystaniu zwierząt w procedurach objętych doświadczeniem bez uzyskania zgody na ich wykorzystanie (art. 66 ust. 1 pkt 2 z.n.e.). Odnosi się to do sytuacji, w której podmiot podejmujący określoną procedurę doświadczalną wykorzystuje w jej przeprowadzeniu zwierzęta, które nie zostały wcześniej uwzględnione we wniosku kierowanym do lokalnej komisji etycznej, lub jeżeli jest to sprzeczne ze zgodą udzieloną przez lokalną komisję etyczną - dotyczyć to będzie zarówno liczby, jak i rodzajów wykorzystywanych zwierząt doświadczalnych ${ }^{36}$.

${ }^{33}$ Z. GĄDZIK, Prawnokarna ochrona, s. 166n.

${ }^{34} \mathrm{~W}$ literaturze specjalistycznej wskazuje się jako przykład projekt COSMOS (Integrated In Silico Models for the Prediction of Juman Repeated Dose Toxicity of COSMetics to Optimise Safety), którego celem było opracowanie metod określania bezpieczeństwa składników produktów kosmetycznych wobec ludzi, bez konieczności wykorzystania zwierząt, lecz wyłącznie na podstawie użycia odpowiednich modeli obliczeniowych. Efektem powyższego projektu było opracowanie i udostępnienie w otwartym dostępie właściwych narzędzi i wyników badań na potrzeby przewidywania bezpieczeństwa poszczególnych składników. Zob. K. JURKOwSKI, W. PIEKOSZEWSKI, Toksykologia, s. 391.

${ }^{35}$ Zob. Etyczne i prawne uwarunkowania, s. 19.

${ }^{36}$ Z. GĄDZIK, Prawnokarna ochrona, s. 168. Odmiennie: M. MozGAwA w: Pozakodeksowe przestęstwa przeciwko zasobom przyrody i środowisku. Komentarz, red. M. Mozgawa, Warszawa: Wolters Kluwer 2017, s. 204. 
W przypadku testowania składników produktów kosmetycznych na zwierzętach zachowaniem, które może zostać uznane za wypełniające znamiona omawianego czynu, będzie przeprowadzanie procedur doświadczalnych przy użyciu metod narażających zwierzęta doświadczalne na ból, strach, cierpienie, stałe uszkodzenie w organizmie, w sytuacji, gdy następstwa takie można było wyeliminować bądź odpowiednio złagodzić w ramach innej, dającej równie wiarygodne wyniki, metody alternatywnej. Wymóg taki wynika z przepisu art. 5 ust. 4 u.z.n.e., zgodnie z którym alternatywna procedura powinna zostać przeprowadzona przede wszystkim w sposób zakładający wykorzystanie najmniejszej liczby zwierząt oraz zwierząt z najniższą zdolnością odczuwania bólu, cierpienia, dystresu lub skutków trwałego uszkodzenia organizmu. Co więcej, metoda ta powinna powodować jak najmniej bólu, cierpienia lub dystresu, lub w najmniejszym stopniu stwarzać ryzyko trwałego uszkodzenia organizmu zwierząt przy jednoczesnym jak największym prawdopodobieństwie osiągnięcia planowanego wyniku procedury. Jak już wspomniano, wobec testowania na zwierzętach składników produktów kosmetycznych, szczególny nacisk kładziony jest na zastąpienie dotychczasowych metod badawczych na testy, w przypadku których nie przewiduje się udziału zwierząt. Wynika to m.in. z przepisu art. 18 ust. 1 lit. d rozporządzenia nr 1223/2009 wprowadzającego zakaz prowadzenia testów na zwierzętach po dacie, od której wymagane będzie zastąpienie takich testów przez którąś z zatwierdzonych metod alternatywnych. W takim przypadku wykorzystanie $w$ ramach procedury doświadczalnej metody innej niż alternatywna będzie co do zasady skutkowało odpowiedzialnością na gruncie przepisu art. 66 ust. 1 pkt 1 u.z.n.e.

Do innych przejawów bezprawnego zachowania, wypełniającego znamiona czynu stypizowanego $\mathrm{w}$ przepisie art. 66 ust. 1 pkt 1 u.z.n.e., niezależnych od rodzaju i celu przeprowadzanych procedur doświadczalnych, jednakże mogących mieć również miejsce $\mathrm{w}$ ramach testowania składników produktów kosmetycznych, zalicza się wszelkiego rodzaju zaniedbania w ramach prawidłowo przeprowadzanej procedury doświadczalnej. Przyjąć należy, że zachowanie tego typu jest przejawem błędu w sztuce. Sprowadza się bowiem do naruszenia obowiązujących w danym przypadku, wypracowanych na gruncie nauki i praktyki reguł postępowania zawodowego wobec dobra prawnego, jakim jest życie i zdrowie zwierzęcia doświadczalnego. Będzie ono stanowiło naruszenie obowiązku ostrożności postępowania w ramach tego typu działalności ${ }^{37}$. Do innych

${ }^{37}$ Zob. A. LisZEWSKA, Odpowiedzialność karna lekarza za błą w sztuce lekarskiej, Kraków: Państwowy Zakład Wydawnictw Lekarskich 1998, s. 28; por. M. WoLIŃSKA, Odpowiedzialność karna lekarza za błą w sztuce lekarskiej, „Prokuratura i Prawo” 2013, nr 5, s. 19n. 
przejawów narażania zwierząt doświadczalnych na zbędny ból lub cierpienie zaliczyć należy również m.in. ich utrzymywanie w niewłaściwych warunkach bytowych, przeprowadzanie procedur za pomocą niewłaściwego - tj. niedostosowanego do wymogów danego gatunku zwierząt sprzętu, jak również nieusuwanie we wskazanym powyżej zakresie nieprawidłowości, w których zwierzęta narażone są na odpowiednie dolegliwości. Podobnie ocenić należy zaniedbania sprawcy $\mathrm{w}$ zakresie niepodania zwierzęciu środków znieczulających lub łagodzących ból (jeżeli nie ma ku temu przeciwwskazań ${ }^{38}$ ), jak również niezapewnienie mu odpowiednich warunków ograniczających lub eliminujących odczuwanie negatywnych bodźców po zakończeniu badania ${ }^{39}$.

W przypadku, gdy zachowanie sprawcy nie mieści się w ramach legalnej procedury doświadczalnej w rozumieniu przepisów ustawy z dnia 15 stycznia 2015 r. o ochronie zwierząt wykorzystywanych do celów naukowych lub edukacyjnych, nie może on ponieść odpowiedzialności na gruncie art. 66 u.z.n.e. Nie wyłącza to jednak jego odpowiedzialności na zasadach ogólnych - odpowiednio za znęcanie się nad zwierzętami lub nieuzasadnione, lub niehumanitarne pozbawienie ich życia.

Przez znęcanie się nad zwierzętami rozumieć należy zadawanie albo świadome dopuszczanie do zadawania im bólu lub cierpień. Ustawodawca w przepisie art. 6 ust. 2 u.o.z. zawarł przykładowy katalog czynów, które kwalifikować należy jako przejawy znęcania się nad zwierzętami. Nie jest to jednak katalog zamknięty, co oznacza, że również inne zachowania można za nie uznać $^{40}$. Znęcaniem się nad zwierzętami będzie m.in. umyślne zranienie lub okaleczenie zwierzęcia, niestanowiące dozwolonego prawem zabiegu lub procedury (art. 6 ust. 2 pkt 1 u.o.z.). Analogiczną kwalifikację przypisać można również w przypadku przeprowadzania testów produktów kosmetycznych lub ich składników na zwierzętach, jeżeli może to spowodować u nich ból bądź cierpienie.

Jeżeli $\mathrm{w}$ związku z powyższym testowaniem produktów kosmetycznych dojdzie do śmierci zwierzęcia, sprawca może ponieść również odpowiedzialność za nieuzasadnione lub nieuzasadnione i niehumanitarne jego zabicie przepis art. 35 ust. 1a u.o.z. pozostaje bowiem $\mathrm{w}$ zbiegu realnym $\mathrm{z}$ przepisem art. 35 ust. 1 u.o.z. W przepisie art. 6 ust. 1 u.o.z. ustawodawca zawarł zamknięty

\footnotetext{
${ }^{38}$ Wyjątek w tym względzie przewidziany został w przepisie art. 13 ust. 3 u.o.z.n.

${ }^{39}$ Zob. szerzej: Z. GĄDZIK, Prawnokarna ochrona, s. 168n.

${ }^{40}$ Zob. szerzej: M. GABRIEL-WĘGŁOWSKI, Przestępstwa przeciwko humanitarnej ochronie zwierzat, Toruń: Dom Organizatora 2008, s. 98n.; M. MozGawa, Prawnokarne aspekty ochrony zwierząt, [w:] Prawna ochrona zwierząt, red. M. Mozgawa, Lublin: Verba 2002, s. 168n.
} 
katalog przypadków uzasadniających uśmiercenie zwierzęcia ${ }^{41}$. Pozbawienie go życia poza nimi będzie wypełniało znamiona czynu z art. 35 ust. 1 u.o.z. Przez niehumanitarne uśmiercenie lub zabicie zwierzęcia rozumieć należy doprowadzenie go do śmierci w sposób związany z wywołaniem u niego dodatkowego bólu lub cierpienia.

Ustawodawca przewidział szereg środków penalnych, mających zastosowanie w przypadku skazania sprawcy przestępstw z art. 35 ust. 1-2 u.o.z. Dotyczy to: przepadku zwierzęcia (art. 35 ust. 3 u.o.z.), zakazu posiadania wszelkich zwierząt lub zwierząt określonej kategorii (art. 35 ust. 3a-3b u.o.z.), zakazu wykonywania wszelkich lub określonych zawodów, prowadzenia wszelkiej działalności lub wykonywania wszelkich, lub określonych czynności wymagających zezwolenia, które są związane $\mathrm{z}$ wykorzystaniem zwierząt lub oddziaływaniem na nie (art. 35 ust. 4-4a u.o.z.), oraz nawiązki na wskazany cel

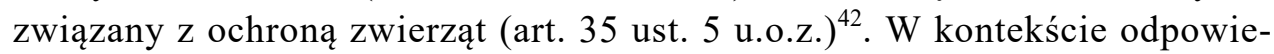
dzialności karnej za bezprawne testowanie produktów kosmetycznych na zwierzętach istotne jest to, że powyższe środki znajdą zastosowanie wyłącznie w przypadku skazania sprawcy za czyn mający miejsce poza procedurą doświadczalną. Nie przewidziano bowiem ich zastosowania wobec osoby skazanej za czyn $\mathrm{z}$ art. 66 u.z.n.e.

\section{PODSUMOWANIE}

Prawnokarna ochrona zwierząt ma szeroki zakres oddziaływania, jednakże analiza wchodzących w jej zakres przepisów może prowadzić do wniosku

\footnotetext{
${ }^{41}$ Dotyczy to: uboju i uśmiercania zwierząt gospodarskich oraz uśmiercania dzikich ptaków i ssaków utrzymywanych przez człowieka w celu pozyskania mięsa i skór; połowu ryb zgodnie z przepisami o rybołówstwie i rybactwie śródlądowym; konieczności bezzwłocznego uśmiercania; działań niezbędnych do usunięcia poważnego zagrożenia sanitarnego ludzi lub zwierząt; zabicia lub poddania ubojowi zwierząt gospodarskich z nakazu powiatowego lekarza weterynarii, o którym mowa w art. 33b ust. 1 u.o.z.; usuwania osobników bezpośrednio zagrażających ludziom lub innym zwierzętom, jeżeli nie jest możliwy inny sposób usunięcia zagrożenia; polowań, odstrzałów i ograniczania populacji zwierząt łownych; usypiania ślepych miotów; czynności podlegających zakazom w stosunku do gatunków chronionych, określonych w ustawie z dnia 16 kwietnia 2004 r. o ochronie zwierząt (Dz.U. z 2018 r., poz. 1614 i 2244) wykonywanych na podstawie właściwych zezwoleń; uśmiercania zwierząt gatunków obcych zagrażających gatunkom rodzimym lub siedliskom przyrodniczym w rozumieniu ustawy z dnia 16 kwietnia 2004 r. o ochronie przyrody - prowadzonych zgodnie z art. 33 oraz przepisami odrębnymi. Zob. także: M. RUDY, Traktat, s. 192; Z. GĄDZIK, Prawnokarna ochrona, s. 125n..; M. MozGAwA, Prawnokarna ochrona zwierzat, Lublin: Verba 2001, s. 17n.

${ }^{42}$ Por. Z. GĄDZIK, Środki karne, s. 75n.
} 
o istnieniu pewnego rodzaju luk w obowiązujących przepisach. W rezultacie wpływa to niekorzystnie na zakres jej rzeczywistej efektywności. Prawidłowość tę można zaobserwować również w przypadku wykorzystywania zwierząt doświadczalnych do procedur doświadczalnych, w ramach których przeprowadza się testy składników produktów kosmetycznych. Pomimo pozornie dużej liczby regulacji odnoszących się do testowania produktów kosmetycznych na zwierzętach, bezsprzecznie można odnieść wrażenie, że ustawodawca zdaje się marginalizować kwestie dotyczące odpowiedzialności karnej za czyny związane $\mathrm{z}$ niezgodnym $\mathrm{z}$ prawem przeprowadzaniem tego typu testów. Ewentualna bezprawność powyższych zachowań jest bowiem egzekwowana przede wszystkim na gruncie sankcji administracyjnych.

Wątpliwości może wywoływać również uchylenie przepisu art. 40 u.o.d.z. i brak jego odpowiednika w ustawie z dnia 15 stycznia 2015 r. o ochronie zwierząt wykorzystywanych w celach naukowych lub edukacyjnych. Zabieg taki, przy jednoczesnym braku wyrażonego wprost zakazu testowania produktów kosmetycznych na zwierzętach, mógłby bowiem, bez jednoczesnej, pogłębionej wykładni, sugerować dekryminalizację takiego zachowania. Stoi to w pewnej sprzeczności z zasadą nullum crimen, nulla poena sine lege certa, nakładającą na ustawodawcę obowiązek tworzenia jasnych i niebudzących zastrzeżeń norm prawnych, uniemożliwiających powstanie wątpliwości co do zakresu ewentualnej odpowiedzialności karnej.

Wydaje się również, że konieczne jest dostosowanie do siebie zakresu ustaw o ochronie zwierząt wykorzystywanych do celów naukowych lub edukacyjnych oraz o produktach kosmetycznych, bądź przynajmniej poczynienie $\mathrm{w}$ jednej z nich stosownych odesłań do treści drugiej z nich. W obecnym brzmieniu pewne zastrzeżenia może bowiem budzić możliwość przeprowadzenia zgodnej z prawem procedury doświadczalnej, której przedmiotem jest testowanie składników produktów kosmetycznych. Słusznym posunięciem byłoby doprecyzowanie, we wspomnianym kontekście, katalogu celów, dla których może być przeprowadzona procedura doświadczalna.

Odnośnie do samych ram odpowiedzialności karnej za bezprawne przeprowadzanie testów składników produktów kosmetycznych na zwierzętach wydaje się, że pewnego rodzaju luką w obowiązującym prawie jest pozbawienie możliwości zastosowania, w stosunku do czynów podlegających kryminalizacji na gruncie przepisów specjalnych, środków penalnych przewidzianych w ustawie z dnia 21 sierpnia 1997 r. o ochronie zwierząt, bądź wprowadzenia do określonych ustaw ich odpowiedników (dostosowanych do charakteru i społecznej szkodliwości wskazanych w nich czynów).Wydaje się, że takie 
rozwiązanie w znacznej mierze zwiększyłoby dolegliwość sankcji (np. zakaz wykonywania określonych zawodów lub prowadzenia danej działalności związanej z wykorzystywaniem zwierząt doświadczalnych) i przełożyłoby się na oddziaływanie prewencyjne we wspomnianym zakresie.

\section{BIBLIOGRAFIA}

\section{ŹRÓDŁA PRAWA}

Rozporządzenie Parlamentu Europejskiego i Rady (WE) nr 1223/2009 z dnia 30 listopada 2009 r. dotyczące produktów kosmetycznych, Dz.U. UE.L Nr 342, poz. 59.

Ustawa z dnia 13 października 1995 r. - Prawo łowieckie, t.j. Dz.U. z 2020 r., poz. 1683.

Ustawa z dnia 21 sierpnia 1997 r. o ochronie zwierząt, t.j. Dz.U. z 2020 r., poz. 638.

Ustawa z dnia 30 marca 2001 r. o kosmetykach, t.j. Dz.U. z 2013 r., poz. 475.

Ustawa z dnia 21 stycznia 2005 r. o doświadczeniach na zwierzętach, Dz.U. Nr 33, poz. 289.

Ustawa z dnia 15 stycznia 2015 r. o ochronie zwierząt wykorzystywanych do celów naukowych lub edukacyjnych, t.j. Dz.U. z 2019 r., poz. 1392.

Ustawa z dnia 4 października 2018 r. o produktach kosmetycznych, Dz.U. poz. 2227.

\section{LITERATURA}

BANASZKIEWICZ Anna: Zarys problematyki przeprowadzania doświadczeń na zwierzętach w przemyśle kosmetycznym, [w:] Kryminologia wobec współczesnych zagrożeń ekologicznych, red. Monika Kotowska, Wiesław Pływaczewski, Olsztyn: Wydawnictwo Uniwersytetu Warmińsko-Mazurskiego 2011, s. 152-158.

BARSKI Dariusz: Wybrane testy toksykologiczne z użyciem zwierząt laboratoryjnych, [w:] Zwierzęta laboratoryjne. Patologia i użytkowanie, red. Józef Szarek, Magdalena Szweda, Emilia Strzyżewska, Olsztyn: Wydawnictwo Uniwersytetu Warmińsko-Mazurskiego 2013, s. 135-146.

BiAŁOCERKIEWICZ Jan: Status prawny zwierząt. Prawa zwierząt czy prawna ochrona zwierząt, Toruń: Dom Organizatora 2005.

BORKOWSKI Mirosław: Prawo kosmetyczne. Zarys prawa polskiego i europejskiego, Gdańsk: Wydawnictwo Gdańskiej Szkoły Wyższej 2015.

BuczKo Włodzimierz: Toksykologia ogólna, [w:] Farmakodynamika. Podręcznik dla studentów farmacji, red. Waldemar Janiec, Jolanta Krupińska, Warszawa: Wydawnictwo Lekarskie PZWL 1999.

CARBone Larry: What Animals Want: Expertise and Advocacy in Laboratory Animal Welfare Policy, Oxford: Oxford Scholarship Online 2004.

CHOdorowska Anna: Przeprowadzanie doświadczeń na zwierzętach w świetle przepisów prawa polskiego i międzynarodowego, [w:] Prawnokarne i kryminologiczne aspekty ochrony środowiska, red. Wiesław Pływaczewski, Olsztyn: Wydawnictwo Uniwersytetu Warmińsko-Mazurskiego 2012, s. 217-232.

ECOBICHON Donald: The Basis of Toxicity Testing, New York: CRC Press LLC 1997. 
Etyczne i prawne uwarunkowania wykorzystywania zwierząt w pracy dydaktycznej i badaniach naukowych, oprac. Zygmunt Giżejewski [i in.], Olsztyn: Wydawnictwo Uniwersytetu Warmińsko-Mazurskiego 2001.

Fox Michael: Laboratory animal husbandry. Ethology, Welfare and Experimental Variables, New York: State University of New York Press 1986.

GABRIEL-WęGıowski Michał: Przestępstwa przeciwko humanitarnej ochronie zwierząt, Toruń: Dom Organizatora 2008.

GĄDZIK Zuzanna: Prawnokarna ochrona zwierząt wykorzystywanych w procedurach doświadczalnych, Lublin: Wydawnictwo KUL 2018.

GĄDZIK Zuzanna: Środki karne, przepadek zwierzęcia i nawiązka w ustawie z dnia 21 sierpnia 1997 r. o ochronie zwierząt, „Prokuratura i Prawo” 2019, nr 3, s. 75-95.

GoldBerg Alan, HARTUNG Thomas: Na ratunek królikom doświadczalnym, „Świat Nauki” 2006, nr 3, s. 70-78.

GomóŁKa Ewa, Groszek Barbara: Rola i znaczenie badań toksykologicznych, [w:] Zarys toksykologii klinicznej, red. Janusz Pach, Kraków: Wydawnictwo Uniwersytetu Jagiellońskiego 2009, s. 71-84.

JuROwSKI Kamil, PIEKOSZEWSKI Wojciech: Toksykologia i ocena bezpieczeństwa kosmetyków, Warszawa: Wydawnictwo Lekarskie PZWL 2019.

KRECHNIAK Jerzy: Toksykologia - zakres działania i kierunki rozwoju, [w:] Toksykologia współczesna, red. Witold Seńczuk, Warszawa: Wydawnictwo Lekarskie PZWL 2006, s. 24-25.

KuRZĘPA Bolesław: Ustawa o kosmetykach z komentarzem, Toruń: Dom Organizatora 2009.

LISZEwSKA Agnieszka: Odpowiedzialność karna lekarza za błąd w sztuce lekarskiej, Kraków: Państwowy Zakład Wydawnictw Lekarskich 1998.

Monamy Vaughan: Animal experimentation. A guide to the issues, Cambridge: Cambridge University Press 2000.

Moskalewski Stanisław, MystKowska Ewa, Kiss Ewa: Test Draize'a i alternatywne metody oceny działania drażniącego substancji chemicznych, „Roczniki Państwowego Zakładu Higieny” 1995, nr 2, s. 163-168.

MozGAwA Marek: Prawnokarna ochrona zwierząt, Lublin: Verba 2001.

MozGAwA Marek: Prawnokarne aspekty ochrony zwierząt, [w:] Prawna ochrona zwierząt, red. Marek Mozgawa, Lublin: Verba 2002, s. 168-184.

MroczKowsKi Sławomir, FrIeSKe Anna: Prawne i etyczne aspekty inżynierii biomedycznej. Eksperymenty na zwierzętach i badania kliniczne wyrobów medycznych, Bydgoszcz: Wydawnictwa Uczelniane Uniwersytetu Technologiczno-Przyrodniczego 2014.

NowickA Izabela: Wykorzystanie zwierząt do badań nad kosmetykami w polskim systemie prawnym - zarys problemu, [w:] Meandry prawa - teoria i praktyka. Księga jubileuszowa prof. zw. dra hab. Mieczysława Goettela, red. Emil W. Pływaczewski, Janusz Bryk, Szczytno: Wydawnictwo Wyższej Szkoły Policyjnej 2017, s. 367-376.

PATON William: Człowiek i mysz: badania medyczne na zwierzętach, Warszawa: Wydawnictwo Naukowe PWN 1997.

PiAstowsKa-Ciesielska Agnieszka, OChĘDALSKI Tomasz: Metodologia badań in vitro, Łódź: Biuro Promocji i Wydawnictw Uniwersytetu Medycznego w Łodzi 2010.

PIETRZyKowski Tomasz: Spór o prawa zwierząt, Katowice: Sonia Draga 2007. 
Pozakodeksowe przestępstwa przeciwko zasobom przyrody i środowisku. Komentarz, red. Marek Mozgawa, Warszawa: Wolters Kluwer 2017.

Prawo karne, red. Alicja Grześkowiak, Krzysztof Wiak, Warszawa: C.H. Beck 2017.

RADECKI Wojciech: Ustawy o ochronie zwierząt. Komentarz, Warszawa: Difin 2015.

RADZIKOWSKI Cezary: Ocena tzw. metod alternatywnych w badaniach biomedycznych, „Nauka” 1995, nr 1, s. 150-157.

Rowan Andrew: Of Mice, Models, and Men: A Critical Evaluation of Animal Research, New York: SUNY Press 1984.

RUDY Michał: Traktat o uśmiercaniu zwierząt, Warszawa: Wydawnictwo Uniwersytetu SWPS 2019.

Russell William, Burch Rex: The Principles of Humane Experimental Technique (chapter 6 Reduction), http://altweb.jhsph.edu/pubs/books/humane_exp/chap6a [dostęp: 21.01.2021].

SMAGA Łukasz: Ochrona humanitarna zwierząt, Białystok: Agencja Wydawniczo-Edytorska EkoPress 2010.

WĄSIK Damian: Ustawa o kosmetykach. Komentarz, Warszawa: Wolters Kluwer 2016.

WoLIŃSKA Magdalena: Odpowiedzialność karna lekarza za błąd w sztuce lekarskiej, „Prokuratura i Prawo" 2013, nr 5, s. 19-35.

\section{PRAWNOKARNA OCENA TESTOWANIA PRODUKTÓW KOSMETYCZNYCH NA ZWIERZĘTACH}

$$
\text { Streszczenie }
$$

Artykuł dotyczy prawnokarnych aspektów testowania na zwierzętach produktów kosmetycznych lub ich składników. Zagadnienie to nie traci wciąż swojej aktualności - zarówno uwzględniając rozwój nauki i technologii, jak i biorąc pod uwagę modyfikację przepisów prawnych oraz społeczną ocenę tego typu zachowań. $Z$ uwagi na rolę, jaką pełnić mogą testy na zwierzętach we wskazanym kontekście, zakwalifikować należy je jako formę testowania toksyczności lub badania bezpieczeństwa, mieszczących się w ramach procedur, w rozumieniu przepisów ustawy z 15 stycznia 2015 r. o ochronie zwierząt wykorzystywanych do celów naukowych lub edukacyjnych. $Z$ tego względu wszelkiego rodzaju nadużycia w zakresie przeprowadzania takich testów powinno się analizować przez pryzmat odpowiedzialności karnej na gruncie powyższej ustawy (narażanie zwierząt na niepotrzebny ból, strach, cierpienie lub trwałe uszkodzenie organizmu) lub ustawy z 21 sierpnia 1997 r. o ochronie zwierząt (znęcanie się nad zwierzętami oraz niehumanitarne lub nieuzasadnione pozbawienie ich życia). Przyjęcie odpowiedniej wykładni i zastosowanie właściwych przepisów jest szczególnie istotne, biorąc pod uwagę uchylenie dotychczasowej ustawy z 30 marca 2001 r. o kosmetykach i wejście w życie nowych regulacji w ramach ustawy z 4 października 2018 r. o produktach kosmetycznych, a także w związku z surowymi karami pieniężnymi grożącymi za naruszenie zakazu testowania kosmetyków na zwierzętach.

Celem artykułu jest dokonanie prawnokarnej oceny przeprowadzania testów kosmetyków na zwierzętach w zależności od spełnienia wymogów formalnych przewidzianych dla procedur doświadczalnych z wykorzystaniem zwierząt. Poruszono również kwestie znaczenia ochrony humanitarnej zwierząt, warunków przeprowadzenia legalnych procedur doświadczalnych, stosowania 
metod alternatywnych w ich ramach oraz potencjalnych konsekwencji prawnych związanych ze skazaniem za przestępstwo wymierzone w ochronę humanitarną zwierząt doświadczalnych.

Słowa kluczowe: ochrona zwierząt; znęcanie się nad zwierzętami; produkty kosmetyczne; procedury doświadczalne

\section{CRIMINAL LAW ASPECTS OF TESTING COSMETIC PRODUCTS ON ANIMALS}

\section{Su m m a ry}

Article deals with criminal law aspects of animal testing of cosmetic products or their ingredients. This issue does not lose its relevance - taking into account the development of science and technology as well as taking into account the modification of legal regulations and the social assessment of this type of behavior. Due to the importance of animal testing in the indicated context, they should be qualified as a form of toxicity testing or safety testing, falling within the procedures as defined in the Protection of animals used for scientific or educational purposes Act of 15th January 2015. For this reason, any kind of abuse in conducting such tests should be analyzed through the prism of criminal liability under the above Act (exposure of animals to unnecessary pain, fear, suffering or permanent damage to the organism) or the Protection of Animals Act of 21st August 1997 (abuse over animals and inhumane or unjustified deprivation of their lives). Adoption of the relevant interpretation and application of relevant provisions is particularly important, considering the repeal of the current Cosmetics Act of 30th March 2001 and the entry into force of new regulations under the Cosmetics products Act of 4 October 2018, as well as in relation to financial penalties for violating the ban on testing cosmetics on animals.

The purpose of the article is to make a criminal law assessment regarding the testing of cosmetics on animals, depending on compliance with formal requirements for experimental procedures using animals. The issues of the importance of humanitarian protection of animals, conditions for conducting legal experimental procedures, the use of alternative methods within them as well as the potential legal consequences related to conviction for a crime aimed at the humanitarian protection of experimental animals were also raised.

Keywords: animal protection; animal abuse; cosmetic products; experimental procedures 